\title{
Microsatellites for detecting inconsistencies in Capsicum cultivars registration in Brazilian database: more than meets the eye
}

\author{
Carlos Diego de O Azevedo ${ }^{1} \mathbb{D}$; Rosana Rodrigues ${ }^{1} \mathbb{D}$; Cláudia P Sudré ${ }^{1 \mathbb{D}}$
}

${ }^{1}$ Universidade Estadual do Norte Fluminense Darcy Ribeiro (UENF), Campos dos Goytacazes-RJ, Brasil; carlosdiego_oliveira@yahoo. com.br; rosana@uenf.br; cpombo@uenf.br

\begin{abstract}
In Brazil, cultivars are registered by National Register of Cultivars (RNC), which besides enabling commercialization of cultivar propagative material, also guarantees the producers genetic purity and identity of propagules. However, it is possible that the information about registration and commercialization of some cultivars is inaccurate. This study aims to analyze the use of microsatellite markers to detect inconsistencies in data of Capsicum spp. cultivars obtained from the official database (CultivarWeb). Seven cultivars were evaluated, three of them were through genetic identity analysis (Amarela Comprida, De Cayenne and Cayenne Long Slin) and the others were used as standard for the species C. annuum, $C$. frutescens and C. chinense. Thirty-three microsatellite loci were polymorphic and presented 76 alleles (an average of 2.3 alleles/ locus). Fixation Index (F) showed high homozygosis and estimators of genetic diversity (Ho and I) presented low genetic diversity among cultivars. The molecular analysis, represented in a dendrogram and in Principal Coordinate Analysis Chart (PCOA), showed that the investigated cultivars belong to $C$. annuum, contrary to what is registered in CultivarWeb, which indicates that such cultivars belong to the species $C$. frutescens. Thus, the authors recommend that the data in the CultivarWeb should be checked and enhanced.
\end{abstract}

Keywords: Capsicum spp., microsatellites, registered cultivars.

\section{RESUMO}

Microssatélites na detecção de inconsistências no registro de cultivares de Capsicum em banco de dados brasileiro: além do que o olho pode ver

No Brasil, o registro de cultivares é feito com cadastramento no Registro Nacional de Cultivares (RNC), o qual, além de habilitar a comercialização do material propagativo da cultivar, garante ao produtor pureza e identidade genética dos propágulos. Mas, é possível que as informações fornecidas para o registro e comercialização das cultivares estejam imprecisas. Este trabalho relata o uso de marcadores microssatélites na detecção de inconsistências nos dados de cultivares de Capsicum spp. no banco de dados oficial (CultivarWeb). Sete cultivares foram avaliadas, sendo três em análise de identidade genética (Amarela Comprida, De Cayenne e Cayenne Long Slin) e as demais foram referência para as espécies C. annuum, C. frutescens e $C$. chinense. Trinta e três locos microssatélites foram polimórficos e apresentaram 76 alelos (média de 2,3 alelos/loco). O Índice de Fixação (F) apontou alta homozigose e os estimadores de diversidade genética (Ho e I) revelaram baixa diversidade genética entre as cultivares. A análise molecular, representada no dendrograma e no gráfico da Análise de Coordenadas Principais (PCOA), mostrou que as cultivares investigadas são da espécie $C$. annuum, ao contrário do que consta registrado no CultivarWeb, que informa a espécie das referidas cultivares como C. frutescens. Recomenda-se, portanto, que a checagem dos dados inseridos no CultivarWeb seja aprimorada.

Palavras-chave: Capsicum spp., microssatélites, cultivares registradas.

\section{Received on November 16, 2018; accepted on July 5, 2019}

$\mathrm{R}^{\mathrm{c}}$ egistro Nacional de Cultivares [(RNC) National Register of Cultivars] is responsible for, previously, qualifying cultivars and species, for production and marketing of seeds and seedlings in the Country, regardless of the group to which they belong, such as forest, forage, fruit, large crops, vegetables and ornamentals. RNC aims to regulate the use of cultivars with significant potential for national agriculture which, besides being distinct, homogeneous and stable, have an identified value of cultivation and use (VCU).

Registration of a cultivar is an important tool to protect both farmers and breeders. Cultivar registration ensures that farmers do not buy seeds and seedlings which are not evaluated according to edaphoclimatic conditions in Brazil. Considering breeders and breeding program, cultivar registration, besides ensuring the genetic identity and varietal quality of cultivars, protects the improved cultivars against degradation due to mechanical mixing, crossbreeding, name or denomination changes and other accidental occurrences (Carvalho et al., 2009).

RNC was established by the Ministerial Order No. 527, of December 31, 1997, by Ministério de Agricultura, Pecuária e Abastecimento [(MAPA) Ministry of Agriculture, Livestock and Food Supply]. Later, in the early $21^{\text {st }}$ 
century, RNC became governed by the Law No. 10.711, of August 5, 2003, and regulated by Decree No. 5,153, July 23, 2004. Ever since, RNC has been under the responsibility of Coordenação de Sementes e Mudas [(CSM) Seeds and Seedlings Coordination], Departamento de Fiscalização de Insumos Agrícolas [(DFIA) Department of Agricultural Inputs Inspection], Secretaria de Defesa Agropecuária [(DAS) Secretariat of Agricultural Defense] of Ministério de Agricultura, Pecuária e Abastecimento (Ministry of Agriculture, Livestock and Supply).

Therefore, according to the enactment of current legislation, to produce and commercialize seeds, seedlings and other propagative structures in Brazil, the producer/breeder, duly registered in RENASEM (National Register of Seeds and Seedlings), should submit the cultivar to Value for Cultivation and Use (VCU) testing, before applying for cultivar registration in RNC (Law No. 10.711/2003).

Through a database maintained on its website, called CultivarWeb, the Ministério de Agricultura, Pecuária e Abastecimento [(MAPA) Ministry of Agriculture, Livestock and Supply] allows to visualize the cultivars registered in Brazil according to genus or species of interest. In June 2019 , the system indicates that 39,331 cultivars were registered in the Country. However, as the available information is obtained by formal declaration from the maintainer through the cultivar application documentation, some inaccuracies or inconsistencies may occur.

This study was carried out since a suspicion of inconsistency arose. This was regarding the species information attributed to three cultivars: Amarela Comprida, De Cayenne and Cayenne Long Slin, which would be used in a DNA fingerprinting assay with cultivars developed by Capsicum spp. breeding program at Universidade Estadual do Norte Fluminense Darcy Ribeiro (UENF). The suspicion is due to the fact that both in seed packaging and in official database (CultivarWeb) these cultivars are presented as belonging to Capsicum frutescens, however, the agronomic traits indicate that such cultivars actually belong to Capsicum annuит.

Molecular markers, mainly the microsatellite markers, are useful tools to characterize Capsicum spp. germplasm and other species of vegetables. Moreover, an application of molecular characterization, which is in expansion, consists of using the characterization to test or prove the identity and genetic purity of commercial cultivars for intellectual property and for advocacy of breeder or maintainer. Regarding the security and protection of intellectual property rights, studies of molecular characterization of pumpkin (Sim et al., 2015), potato (Favoretto et al., 2011), pepper and sweet pepper (Kumar et al., 2001; Kwon et al., 2005) cultivars can be found.

The aim of this study was to use microsatellite markers to characterize Capsicum spp. genotypes, in order to check at DNA level, which species of genus Capsicum spp. belongs, specifically the genotypes represented by the cultivars Amarela Comprida, De Cayenne and Cayenne Long Slin and, solve issues of available information on Cultivarweb related to the species of these cultivars.

\section{MATERIAL AND METHODS}

\section{Germplasm}

Seven cultivars were used in trials for molecular characterization: UENF Campista, Cascadura Ikeda, Amarela Comprida, De Cayenne, Cayenne Long Slin, Malagueta and UENF 2154.

Cultivars UENF Campista and Cascadura Ikeda were used as standards for Capsicum annuum species, since there is no doubt they belong to this species. Cultivar Malagueta and UENF 2154 were used as standards for $C$. frutescens and C. chinense species, respectively.

Plants were grown for 45 days in $500 \mathrm{~mL}$ pots in a greenhouse at Unidade de Apoio à Pesquisa of Campus Leonel Brizola from Universidade Estadual do Norte Fluminense Darcy Ribeiro, in the municipality of Campos dos Goytacazes, Rio de Janeiro, Brazil.
Then, leaf samples were collected for DNA extraction. In order to check homozygous level of the sampled cultivars and the genetic purity of the seeds, each cultivar was represented by a bulk composed of five plants.

\section{DNA extraction}

For DNA extraction, leaf samples of each one of seven cultivars and, approximately, $300 \mathrm{mg}$ leaf tissue was macerated and transferred into $1.5 \mu \mathrm{L}$ tubes and immersed in liquid $\mathrm{N}_{2}$ for DNA extraction according to Doyle \& Doyle protocol (1990).

DNA was quantified using Qubit 3.0 fluorometer (Invitrogen). Afterwards, samples were diluted and standardized at $5 \mathrm{ng} \mathrm{l}^{-1}$ to be submitted to polymerase chain reactions (PCR).

\section{Amplification reactions}

Eighty microsatellite markers available in literature (Lee et al., 2004; Minamiyama et al., 2006; Yi et al., 2006) were selected based on information about polymorphism level, specificity for $C$. annuum and position in the genome (Table 1).

The authors decided to use microsatellite markers due to constant recommendation in International Union for the Protection of New Varieties of Plants (UPOV, 2010).

Amplification reactions were prepared in $13 \mu \mathrm{L}$ final volume, containing reagents: $0.12 \mu \mathrm{L}$ Taq DNA polymerase, $1.3 \mu \mathrm{L} 10 \mathrm{x}$ buffer $(500 \mathrm{mM}$ $\mathrm{KCl}, 100 \mathrm{mM}$ Tris-HCl, $\mathrm{pH} 8.3), 1.0 \mu \mathrm{L}$ $25 \mathrm{mM} \mathrm{MgCl} 21.5 \mu \mathrm{L}$ dNTP $(0.1 \mathrm{mM}$ of each of the deoxyribonucleotides), $1.0 \mu \mathrm{L}$ of $5 \mathrm{Mm}$ primer and $6.08 \mu \mathrm{L}$ of ultrapure water.

Then, the reactions were conducted in a thermocycler model Veriti, Applied Biosystems, following: $4 \mathrm{~min}$ at $94^{\circ} \mathrm{C}$ for initial denaturation; 38 cycles including $94^{\circ} \mathrm{C}$ for $1 \mathrm{~min}, 52-60^{\circ} \mathrm{C}$ for $1 \mathrm{~min}$ (depending on primer used), $72^{\circ} \mathrm{C}$ for $3 \mathrm{~min}$; and a final extension at $72^{\circ} \mathrm{C}$ for $7 \mathrm{~min}$.

Amplified DNA fragments were separated in high resolution agarose gel concentrated at $4 \%$ by a horizontal electrophoresis system. The PCR products, before being electrophoresed, 
were stained with Blue Juice and Gel Red (1:1) solution. Then, the gels were submitted to ultraviolet light photocumentation (Minibis Pro Photocumenter - Bio-imaging System).

Afterwards, only polymorphic microsatellites markers for the material under evaluation were used for the elaboration of numerical spreadsheet based on the pattern of the bands observed in the gel images.

\section{Data analysis}

At beginning, the authors used programs GenAlEx (Peakall \& Smouse, 2012) and PowerMarker (Liu \& Muse, 2005) for math determination of the following genetic diversity estimators for the evaluated accessions: number of alleles, number of effective alleles, number of loci with private alleles per access; fixation index; observed heterozygosity and Shannon's Index.

Then, genetic diversity analysis among cultivars was performed using Genes program (Cruz, 2013), data were processed by complement of the weighted similarity index. This analysis generated a matrix with measures of dissimilarity between genotypes, which was used for clustering analysis by hierarchical method of medium group bonding [(UPGMA) Unweighted Pair Group Method with Arithmetic Means] using Genes program and Principal Coordinate Analysis in the GenAlEx Program.

\section{RESULTS AND DISCUSSION}

Among 80 microsatellites markers tested, only 33 showed polymorphism for the evaluated material; for this reason, only these markers were computed and used for data analysis (Table 2).

These 33 analyzed microsatellites markers generated 76 alleles $(\mathrm{Na})$, showing an average of 2.3 alleles per locus. This result is due to the fact that the evaluated genotypes are inbred lines at a high level of homozygosis. The number of effective alleles (Ne) ranged from 1.153 (CAMS-451) to 3.000 (Hpms E016), with an average of 1.691. These values are in accordance to what is expected when investigated genotypes belong to autogamous species and are genetically closely related.

Considering the values of genetic diversity estimates (Ho and I), the authors noticed that the genetic diversity among the accessions can be considered medium, which corroborates the fact that these evaluated genotypes are autogamous species belonging to the same gene complex (C. annuum complex). This complex comprises $C$. annuum, $C$. frutescens, $C$. chinense and $C$. chacoense. Therefore, loci were expected to tend to lower level of polymorphism and, as a result, to find low level of genetic diversity among cultivars of different species and among cultivars of the same species.

The values observed in Fixation Index (F) $(\mathrm{F}=-0.750$ to 1.000$)$ show medium to high homozygosis of cultivars per se considering investigated loci. The authors highlight that Fixation Index (F) may show values from -1 to +1 . Values close to zero show random crossings; negative values show excess of heterozygosity, due to heterozygous selection and biased mating between similar phenotypes; finally, high positive values show high inbreeding (Peakall \& Smouse, 2012). In addition, we might infer that Fixation Index still corresponds to an estimate of differentiation between and among cultivars, as well as promote diagnosis of the variability of each locus in terms of the level of homozygosis or heterozygosis.

In another analysis, the authors noticed private alleles (Ap) for each cultivar among the evaluated loci. 'De Cayenne' showed the largest number of private alleles $(\mathrm{Ap}=18)$, whereas 'Malagueta' showed the lowest number of private alleles $(\mathrm{Ap}=6)$ (Table 3$)$. $C$. annuum cultivars showed a number of private alleles much superior to the observed for $C$. frutescens and $C$. chinense.

The detection of private alleles, besides being an indicator of the occurrence or not of gene flow, reflects the level of genetic relationship between the evaluated accessions or populations (Szpiech \& Rosenberg, 2011). Thus, the greater the number of private alleles, the lower the gene flow and, consequently, the carrier of the largest number of private alleles tends to be the most genetically distant from the others of the same species, genus or population.

Considering the analysis of private alleles, we observed great genetic divergence among cultivars which admittedly belong to the species $C$. frutescens and $C$. chinense, respectively, 'Malagueta' and UENF 2154, cultivars Amarela Comprida, De Cayenne and Cayenne Long Slin, as well as the cultivars used as standard for $C$. annuum species ('Cascadura Ikeda' and 'UENF Campista').

Due to an expressive number of private alleles which were detected through genotype, these markers can be recommended for studies on molecular characterization of Capsicum ssp. accessions, or for other trials aiming to obtain DNA fingerprints.

The analysis of genetic diversity among accessions generated a dissimilarity matrix, in which a correlation of 0.99 with cophenetic value matrix was verified. The closer the value of the cophenetic correlation coefficient (CCC) is to 1, the smaller the individual cluster distortion using the UPGMA method (Silva \& Dias, 2013). Thus, the high value of the cophenetic correlation coefficient observed corresponds to a high consistency and reliability of clusterings observed in the dendrogram.

Using the dissimilarity matrix, a dendrogram was generated by the clustering analysis performed using MEGA software applying UPGMA method. Three groups of cultivars were formed (Figure 1) which are reunited considering the species. The establishment of the groups was done subjectively, based on the sharp changes in levels, associated with prior knowledge of the material under study.

The first group consisted of cultivars related to C. annuum: UENF Campista, Cascadura Ikeda, Amarela Comprida, De Cayenne and Cayenne Long Slin. The composition of the first group was expected, since cultivars UENF Campista and Cascadura Ikeda were used as standard for $C$. annuum and due to the hypothesis that cultivars Amarela Comprida, De Cayenne and Cayenne 
Long Slin also belong to this species. Cultivar Malagueta was the only one which represented the second group, used as standard for $C$. frutescens. The third group consisted only of cultivar UENF 2154, belonging to C. chinense.
Clustering analysis, specifically regarding the composition of the first group, proves that cultivars Amarela Comprida, De Cayenne and Cayenne Long Slin do not belong to $C$. frutescens, as it can be found on information board of these cultivars in CultivarWeb (data bank), but, in fact, they belong to $C$. annuum.

In Principal Coordinate Analysis (PCOA) (Figure 2), cultivars were distributed and clustered in three

Table 1. Microsatellite markers specific for Capsicum spp. used. Campos dos Goytacazes, UENF, 2017.

\begin{tabular}{|c|c|c|c|c|}
\hline Loci & Forward primer (5'-3') & Reverse primer & $\begin{array}{r}\text { Linking } \\
\text { group }\end{array}$ & Source \\
\hline Hpms $1-1 *$ & F tcaacccaatattaaggtcacttcc & R ccaggcggggattgtagatg & 1 & Lee et al. 2004 \\
\hline Hpms 1-3 & F tgggaaataggatgcgctaaacc & $\mathrm{R}$ aactttaagactcaaaatccataacc & 9 & Lee et al. 2004 \\
\hline Hpms 1-5 & F ccaaacgaaccgatgaacactc & $\mathrm{R}$ gacaatgttgaaaaaggtggaagac & 6 & Lee et al. 2004 \\
\hline Hpms $1-41$ & F gggtatcatccgttgaaagttagg & $\mathrm{R}$ caagaggtatcacaacatgagagg & 1 & Lee et al. 2004 \\
\hline Hpms 1-43 & F aaccagcaatcccatgaaaacc & R gggctttggggagaatagtgtg & 1 & Lee et al. 2004 \\
\hline Hpms 1-62 & F catgaggtctcgcatgatttcac & $\mathrm{R}$ ggagaaggaccatgtactgcagag & 1 & Lee et al. 2004 \\
\hline Hpms 1-69 & F cggtggcatgtagtttctggag & $\mathrm{R}$ aagacatgaaatccacaagttttc & 4 & Lee et al. 2004 \\
\hline Hpms 1-117 & F acccaaatttgccttgttgat & $\mathrm{R}$ aatccataaccttatcccataaa & 9 & Lee et al. 2004 \\
\hline Hpms 1-139 & F ccaacagtaggacccgaaaatcc & $\mathrm{R}$ atgaaggctactgctgcgatcc & 1 & Lee et al. 2004 \\
\hline Hpms 1-148 & F ggcggagaagaactagacgattagc & R ccacccaatccacatagacg & 1 & Lee et al. 2004 \\
\hline Hpms 1-155 & F acgaggcccaagctgttatgtc & $\mathrm{R}$ ttgtcccgactctccattgacc & 1 & Lee et al. 2004 \\
\hline Hpms $1-165$ & F ggctatttccgacaaaccctcag & $\mathrm{R}$ ccattggtgttttcactgttgtg & 4 & Lee et al. 2004 \\
\hline Hpms $1-168$ & F gccccgatcaatgaatttcaac & $\mathrm{R}$ tgatttttgggtggagagaaaacc & 16 & Lee et al. 2004 \\
\hline Hpms $1-172$ & F gggtttgcatgatctaagcatttt & $\mathrm{R}$ cgctggaatgcattgtcaaaga & 11 & Lee et al. 2004 \\
\hline Hpms 1-173 & F tgctgggaaagatctcaaaagg & $\mathrm{R}$ atcaaggaagcaaaccaatgc & 3 & Lee et al. 2004 \\
\hline Hpms 1-214 & F tgcgagtaccgagttctttctag & R ggcagtcctgggacaactcg & 1 & Lee et al. 2004 \\
\hline Hpms 1-216 & F tgcttgttgtttttaccetcagc & $\mathrm{R}$ agtgaaaggtgggcaacagc & 7 & Lee et al. 2004 \\
\hline Hpms 1-227 & F cgtggcttcaagtatggactgc & R ggggcggaacttttcttatcc & 7 & Lee et al. 2004 \\
\hline Hpms 1-274 & F tcccagacccetcgtgatag & $\mathrm{R}$ tcctgctccttccacaactg & 7 & Lee et al. 2004 \\
\hline Hpms 1-281 & F tgaggcagtggtatggtctgc & $\mathrm{R}$ cccgagttcgtctgccaatag & 1 & Lee et al. 2004 \\
\hline Hpms 2-2 & F gcaaggatgcttagttgggtgtc & $\mathrm{R}$ tcccaaaattaccttgcagcac & 11 & Lee et al. 2004 \\
\hline Hpms 2-13 & F tcacctcataagggcttatcaatc & $\mathrm{R}$ tccttaaccttacgaaaccttgg & 1 & Lee et al. 2004 \\
\hline Hpms 2-21 & F tttttcaattgatgcatgaccgata & $\mathrm{R}$ catgtcattttgtcattgatttgg & 10 & Lee et al. 2004 \\
\hline Hpms 2-23 & F ccctcggctcaggataaatacc & $\mathrm{R}$ ccccagactcccactttgtg & 5 & Lee et al. 2004 \\
\hline Hpms 2-24 & F tcgtattggcttgtgatttaccg & $\mathrm{R}$ ttgaatcgaatacccgcaggag & 9 & Lee et al. 2004 \\
\hline Hpms 2-26 & F gggatgtaggaacaaccctaacc & $\mathrm{R}$ tgcatcttttcttcatccctttc & $1,3,5$ & Lee et al. 2004 \\
\hline Hpms 2-45 & F cgaaaggtagttttgggcetttg & $\mathrm{R}$ tgggcccaatatgcttaagagc & 5 & Lee et al. 2004 \\
\hline HpmsAT2-14 & F tttagggtttccaactcttcttcc & $\mathrm{R}$ ctaaccccaccaagcaaaacac & 4 & Lee et al. 2004 \\
\hline HpmsAT2-20 & F tgcactgtcttgtgttaaaatgacg & $\mathrm{R}$ aaaattgcacaaatatggctgctg & 6 & Lee et al. 2004 \\
\hline HpmsCaSIG19 & F catgaatttcgtcttgaaggtccc & $\mathrm{R}$ aagggtgtatcgtacgcagcctta & 7 & Lee et al. 2004 \\
\hline HpmshpMADS & F tgctttcaaaacaatttgcatgg & R vgcgtctaatgcaaaacacacattac & 1 & Lee et al. 2004 \\
\hline CACCEL1 & F ctctaataggcaatagctcacatgc & R gcagtctcccagaacgttgtcc & 1 & Lee et al. 2004 \\
\hline AA840689 & F gacaacataggcggacctttgg & $\mathrm{R}$ tgctttaggtctacgtccttgcac & 3 & Lee et al. 2004 \\
\hline AA840692 & F tggaagtgattactggaaaccatgc & R ggggtttagtcatggaatcttttgc & 3 & Lee et al. 2004 \\
\hline AA840721 & F cactttgatacgtgaacacttcc & $\mathrm{R}$ agtttgcactggtcetgctc & 7 & Lee et al. 2004 \\
\hline AF242731 & F gggctgacggccattaagaac & $\mathrm{R}$ cagacagctagaaagagaggaattctg & 16 & Lee et al. 2004 \\
\hline AF244121 & $\mathrm{F}$ tacctcetcgecaatccttctg & $\mathrm{R}$ ttgaaagttctttccatgacaacc & 1,3 & Lee et al. 2004 \\
\hline
\end{tabular}


Table 1. continuation

\begin{tabular}{|c|c|c|c|c|}
\hline Loci & Forward primer (5'-3') & Reverse primer & $\begin{array}{r}\text { Linking } \\
\text { group } \\
\end{array}$ & Source \\
\hline CAN010950 & F gattttggtggcagaagaattgg & R tgcactttcgaagcaaacaaacc & 1 & Lee et al. 2004 \\
\hline AF208834 & F tgcaccaaggtccagtaaggttg & R ccaaccaccatggttcatacaag & 6 & Lee et al. 2004 \\
\hline HpmsE001 & F tgccacccataaaattcttaaacca & $\mathrm{R}$ tgcaagatcccaaattgaaatga & 2 & Yi et al. 2006 \\
\hline HpmsE003 & F tttctgcaattcccettgttca & R cagcagagcettcagtagcagc & 2 & Yi et al. 2006 \\
\hline HpmsE004 & F tgggaagagaaattgtgaaagca & $\mathrm{R}$ caatgccaacaatggcatccta & 1 & Yi et al. 2006 \\
\hline HpmsE005 & F tgcctcagtttcccaaccct & $\mathrm{R}$ accaacaccgtaacgcaccc & 3 & Yi et al. 2006 \\
\hline HpmsE006 & F gctgaccgttttcgttttggg & $\mathrm{R}$ caaaattcaaccgcaccaaca & 4 & Yi et al. 2006 \\
\hline HpmsE007 & F ccccatttccecttcccata & R gaggggtcatgttgaaggcaa & 9 & Yi et al. 2006 \\
\hline HpmsE008 & F cccettaacttttaattctagatctgc & $\mathrm{R}$ tcgttgttcctccatcacctca & 3 & Yi et al. 2006 \\
\hline HpmsE009 & F tgcacaaacatcatacacctca & $\mathrm{R}$ cccatgactgatagtccgggtc & 2 & Yi et al. 2006 \\
\hline HpmsE010 & F ctgtttgccaatcaccatcagg & R gctattttccggcgtgtgagag & 3 & Yi et al. 2006 \\
\hline HpmsE011 & F gcagaagaccaaagccctagca & $\mathrm{R}$ tggtttccattgtcactgtatgc & 6 & Yi et al. 2006 \\
\hline HpmsE012 & F aaacgctgaaaaaggcgttgac & $\mathrm{R}$ tgcaccaacttcttccatgcac & 11 & Yi et al. 2006 \\
\hline HpmsE013 & F gcgccaagtgagttgaattgat & $\mathrm{R}$ caccaatccgettgctgttgta & 10 & Yi et al. 2006 \\
\hline HpmsE014 & F ctttggaacatttctttggggg & R gcggacgtagcagtaggtttgg & 6 & Yi et al. 2006 \\
\hline HpmsE015 & F ttgtgagggtttgacactggga & $\mathrm{R}$ ccgagctcgatgaggatgaact & 5 & Yi et al. 2006 \\
\hline HpmsE016 & F ccaagttcaggcccaggagtaa & $\mathrm{R}$ tgcagagaagactcaccagtcc & 3 & Yi et al. 2006 \\
\hline HpmsE019 & $\mathrm{F}$ aagtcatcagctgcaaagacca & $\mathrm{R}$ ttcaacatgcatccagcttctt & 1 & Yi et al. 2006 \\
\hline HpmsE020 & F cccccgagaggaacagaatcat & $\mathrm{R}$ ttccattttggtccagctacca & 7 & Yi et al. 2006 \\
\hline HpmsE021 & F cacactaagcattctgctttcaca & R ggagggaatagtagcggtttgga & 1 & Yi et al. 2006 \\
\hline HpmsE022 & F gcaccagcatcaacatcagcat & $\mathrm{R}$ cagcaggtgaaggacttgcaga & 1 & Yi et al. 2006 \\
\hline HpmsE023 & F tttaacacctctctaaccgtcacc & $\mathrm{R}$ gcgatttcagcccatcaacaat & 11 & Yi et al. 2006 \\
\hline HpmsE024 & F cgagectaaccacccaaatcag & $\mathrm{R}$ aagggaacggagggacgactac & 12 & Yi et al. 2006 \\
\hline HpmsE025 & F tgagcatcccgttatctcaaatca & $\mathrm{R}$ cccaattcttcaggcaatctcc & 9 & Yi et al. 2006 \\
\hline HpmsE026 & F ccaaagtccatcgacgtctcaa & $\mathrm{R}$ atcaaatggcaaaccaggagga & 1 & Yi et al. 2006 \\
\hline HpmsE027 & F tggagaattggtgttacatgaagg & $\mathrm{R}$ ttcggaccettctccatcactt & 1 & Yi et al. 2006 \\
\hline HpmsE029 & F gatggagaagatcgecgacaag & $\mathrm{R}$ tacatcagcaggtttgectcca & 1 & Yi et al. 2006 \\
\hline HpmsE030 & F gaagcaggggecagagctaga & R gcccccaattctcaaacagaga & 3 & Yi et al. 2006 \\
\hline HpmsE031 & F ccctaaatcaaccccaaattcaa & R cccccattacctgactgcaaaa & 10 & Yi et al. 2006 \\
\hline HpmsE033 & F tggatcctcctttctacttcaaca & $\mathrm{R}$ aagggtggtgaaaaggggattt & 1 & Yi et al. 2006 \\
\hline CAMS-156 & F ccctatgetttcacaactcct & $\mathrm{R}$ gacgtggttatgacgataggc & 10 & Minamiyama et al. 2006 \\
\hline CAMS-215 & F cgtgggtggtctaggatgat & R gctggcaagtcactctggat & 7 & Minamiyama et al. 2006 \\
\hline CAMS-311 & F ggtgcgctagagatggagag & $\mathrm{R}$ tttgagtgttcgggactggt & 6 & Minamiyama et al. 2006 \\
\hline CAMS-340 & F tttatgeccattcacaaaataa & R ggacgaattcaccgagtgc & 10 & Minamiyama et al. 2006 \\
\hline CAMS-398 & $\mathrm{F}$ atggtccatggtcagcagat & R gggcagaacagtggatgatt & 7 & Minamiyama et al. 2006 \\
\hline CAMS-405 & F ttcttgggtcccacactttc & $\mathrm{R}$ aggttgaaaggagggcaata & 11 & Minamiyama et al. 2006 \\
\hline CAMS-424 & F tccacagcccacagtgtcta & $\mathrm{R}$ gcttgtggttccgtgatttt & 6 & Minamiyama et al. 2006 \\
\hline CAMS-451 & F tgcattggtgggctaacata & R gctcttgacacaaccccaat & 11 & Minamiyama et al. 2006 \\
\hline CAMS-460 & F cctttcacttcagcccacat & $\mathrm{R}$ accatccgctaagacgagaa & 7 & Minamiyama et al. 2006 \\
\hline CAMS-606 & F gactagtcccegttcaacca & $\mathrm{R}$ tttgcgagaagatgcttcag & 7 & Minamiyama et al. 2006 \\
\hline CAMS-811 & F gaagaaacgaaggatgaacaaaa & $\mathrm{R}$ cctgtttcctcttcctcagc & 9 & Minamiyama et al. 2006 \\
\hline CAMS-844 & F gcaaagaaaaagaaaagcctga & $\mathrm{R}$ ctgcaactgctgcttcattc & 1 & Minamiyama et al. 2006 \\
\hline CAMS-855 & $\mathrm{F}$ aagtgtcaaggaaggggaca & $\mathrm{R}$ cctaaccacccccaaaagtt & 8 & Minamiyama et al. 2006 \\
\hline
\end{tabular}


groups according to genetic relationship and, consequently, according to their respective species. Variation percentage explained by axes 1 and 2 were, respectively, $83.70 \%$ and $11.96 \%$. This result justifies that approximately $95 \%$ of all variability contained in the evaluated genotypes can be explained by the two-dimensional plane with low level of information distortion. Cultivars Amarela Comprida, De Cayenne and Cayenne Long Slin are genetically closer than the cultivars used as standard for $C$. annuum than the cultivars which represent $C$. frutescens and $C$. chinense species (respectively, Malagueta and UENF 2154).

In some studies on morphological characterization, a differentiation among genotypes of different Capsicum species can be obtained (Campos et al., 2016). Thereunto, morphological and agronomic descriptors proposed for Capsicum by IPGRI (International Plant Genetic Resources Institute, renamed Biodiversity International) were used. However, this methodology requires more time and resources than the use of molecular markers.

Results obtained in these studies show a probable inaccuracy in identifying tested cultivars (Amarela Comprida, De Cayenne and Cayenne Long Slin) in relation to the species in CultivarWeb database bank. And it is still worse when one searched on the platform CultivarWeb using the expression "Cayenne long", two different results can be found, apparently, in relation to different cultivars: In one result, the cultivar Cayenne Long Slin is associated with $C$. frutescens species (this cultivar was evaluated in this study), whereas the second result presents cultivar Cayenne long Slim as related to $C$. annuum species. When restricting the search to keyword "Cayenne", seven results are displayed; these are distributed in C. frutescens (cultivars Ardida Cayenne, Ardida Vermelha Cayenne, Cayenne, Cayenne Long Slin and De Cayenne) and $C$. annuum (cultivares Cayenne Long Slim and Dedo de Moça - Cayenne).

Search results on CultivarWeb, as considered in previous paragraphs, show incorrect information, principally because it is recognized in literature that cayenne or cayenne peppers belong exclusively to the species $C$. annuum (Barbero et al., 2014). Specifically, when comparing the Cayenne Long Slin and Cayenne Long Slim cultivars, the question remains whether there is a difference between them or not, besides the misspelling in writing the word slim (thin in thickness, physically thin) in the name of cultivar Cayenne Long Slin. In addition, cultivar Amarela Comprida, although registered as belonging to $C$. frutescens, is recognized and marketed as belonging to $C$. annuum (Pimentas artesanais, 2017).

Table 2. Data analysis of microsatellite loci for Capsicum spp. cultivars in relation to number of alleles $(\mathrm{Na})$, number of effective alleles $(\mathrm{Ne})$, Shannon Index (I), observed heterozygosity (Ho) and Fixation Index (F). Campos dos Goytacazes, UENF, 2017.

\begin{tabular}{lccccc}
\hline Loci & Na & Ne & I & Ho & F \\
\hline Hpms 11 & 2.000 & 1.508 & 0.520 & 0.143 & 0.576 \\
Hpms 13 & 2.000 & 1.690 & 0.598 & 0 & 1.000 \\
Hpms 15 & 3.000 & 1.342 & 0.509 & 0.143 & 0.440 \\
Hpms 141 & 2.000 & 1.690 & 0.598 & 0 & 1.000 \\
Hpms 143 & 2.000 & 1.960 & 0.683 & 0 & 1.000 \\
Hpms 162 & 2.000 & 1.849 & 0.652 & 0.143 & 0.689 \\
Hpms 1117 & 3.000 & 1.556 & 0.656 & 0.143 & 0.600 \\
Hpms 1139 & 2.000 & 1.960 & 0.683 & 0.857 & -0.750 \\
Hpms 1148 & 3.000 & 1.815 & 0.796 & 0.286 & 0.364 \\
Hpms 1173 & 2.000 & 1.690 & 0.598 & 0 & 1.000 \\
Hpms 1216 & 2.000 & 1.324 & 0.410 & 0 & 1.000 \\
Hpms 1281 & 2.000 & 1.690 & 0.598 & 0 & 1.000 \\
Hpms 221 & 3.000 & 2.178 & 0.876 & 0.857 & -0.585 \\
Hpms AT214 & 2.000 & 1.690 & 0.598 & 0 & 1.000 \\
Hpms AT220 & 2.000 & 1.690 & 0.598 & 0 & 1.000 \\
Hpms hpMADS & 2.000 & 1.690 & 0.598 & 0 & 1.000 \\
AA840692 & 2.000 & 1.324 & 0.410 & 0 & 1.000 \\
AF242731 & 2.000 & 1.960 & 0.683 & 0 & 1.000 \\
Hpms E003 & 2.000 & 1.324 & 0.410 & 0 & 1.000 \\
Hpms E004 & 2.000 & 1.690 & 0.598 & 0 & 1.000 \\
Hpms E007 & 2.000 & 1.690 & 0.598 & 0 & 1.000 \\
Hpms E009 & 2.000 & 1.324 & 0.410 & 0 & 1.000 \\
Hpms E014 & 3.000 & 2.333 & 0.956 & 0 & 1.000 \\
Hpms E016 & 3.000 & 3.000 & 1.099 & 0 & 1.000 \\
CAMS-215 & 3.000 & 1.412 & 0.566 & 0.167 & 0.429 \\
CAMS-340 & 2.000 & 1.471 & 0.500 & 0 & 1.000 \\
CAMS-398 & 3.000 & 2.178 & 0.876 & 0.857 & -0.585 \\
CAMS-424 & 2.000 & 1.690 & 0.598 & 0 & 1.000 \\
CAMS-451 & 2.000 & 1.153 & 0.257 & 0.143 & -0.077 \\
CAMS-460 & 2.000 & 1.324 & 0.410 & 0 & 1.000 \\
CAMS-606 & 2.000 & 1.508 & 0.520 & 0.143 & 0.576 \\
CAMS-811 & 3.000 & 1.556 & 0.656 & 0.286 & 0.200 \\
CAMS-855 & 3.000 & 1.556 & 0.656 & 0.143 & 0.600 \\
\hline Total & 55.811 & --- & --- & --- \\
Average & 1.691 & 0.611 & 0.130 & 0.681 \\
\hline & & & & & \\
& 76.000 &
\end{tabular}


Table 3. Private alleles (Ap) detected by microsatellite for each C. anuum, C. frutescens and C. chinense cultivar. Campos dos Goytacazes, UENF, 2017.

\begin{tabular}{|c|c|c|}
\hline Cultivar & Ap & Private alleles per loci \\
\hline $\begin{array}{l}\text { UENF } \\
\text { Campista }\end{array}$ & 16 & $\begin{array}{l}\text { Hpms 13; Hpms 141; Hpms 143; Hpms 162; Hpms 1148; Hpms 1173; Hpms 1281; Hpms } \\
\text { 221; Hpms AT214; Hpms AT220; Hpms hpMADS; AF242731; Hpms E004; Hpms E014; } \\
\text { CAMS-398; CAMS-424. }\end{array}$ \\
\hline $\begin{array}{l}\text { Cascadura } \\
\text { Ikeda }\end{array}$ & 15 & $\begin{array}{l}\text { Hpms 13; Hpms 141; Hpms 162; Hpms 1148; Hpms 1173; Hpms 1281; Hpms 221; Hpms } \\
\text { AT214; Hpms AT220; Hpms hpMADS; AF242731; Hpms E004; Hpms E014; CAMS-398; } \\
\text { CAMS-424. }\end{array}$ \\
\hline $\begin{array}{l}\text { Amarela } \\
\text { Comprida }\end{array}$ & 16 & $\begin{array}{l}\text { Hpms 13; Hpms 141; Hpms 162; Hpms 1148; Hpms 1173; Hpms 1281; Hpms 221; Hpms } \\
\text { AT214; Hpms AT220; Hpms hpMADS; AF242731; Hpms E004; Hpms E014; CAMS-340; } \\
\text { CAMS-398;CAMS-424. }\end{array}$ \\
\hline $\begin{array}{l}\text { De } \\
\text { Cayenne }\end{array}$ & 18 & $\begin{array}{l}\text { Hpms 13; Hpms 141; Hpms 143; Hpms 162; Hpms 1148;Hpms 1173; Hpms 1281; Hpms 221; } \\
\text { Hpms AT214; Hpms AT220; Hpms hpMADS; Hpms E004; Hpms E007; Hpms E014; Hpms } \\
\text { E016; CAMS-398; CAMS-424; CAMS-451. }\end{array}$ \\
\hline $\begin{array}{l}\text { Cayenne } \\
\text { Long Slin }\end{array}$ & 17 & $\begin{array}{l}\text { Hpms 13; Hpms 141; Hpms 143;Hpms 162; Hpms 1148; Hpms 1173; Hpms 1281; Hpms 221; } \\
\text { Hpms AT214; Hpms AT220; Hpms hpMADS; Hpms E004; Hpms E007; Hpms E014; Hpms } \\
\text { E016; CAMS-398; CAMS-424. }\end{array}$ \\
\hline Malagueta & 6 & Hpms 15; Hpms 1117; CAMS-215; CAMS-398; CAMS-460; CAMS-855. \\
\hline $\begin{array}{l}\text { UENF } \\
2154\end{array}$ & 8 & $\begin{array}{l}\text { Hpms 1117; Hpms 1216; Hpms 221; AA840692; Hpms E003; Hpms E009; CAMS-811; } \\
\text { CAMS-855. }\end{array}$ \\
\hline
\end{tabular}

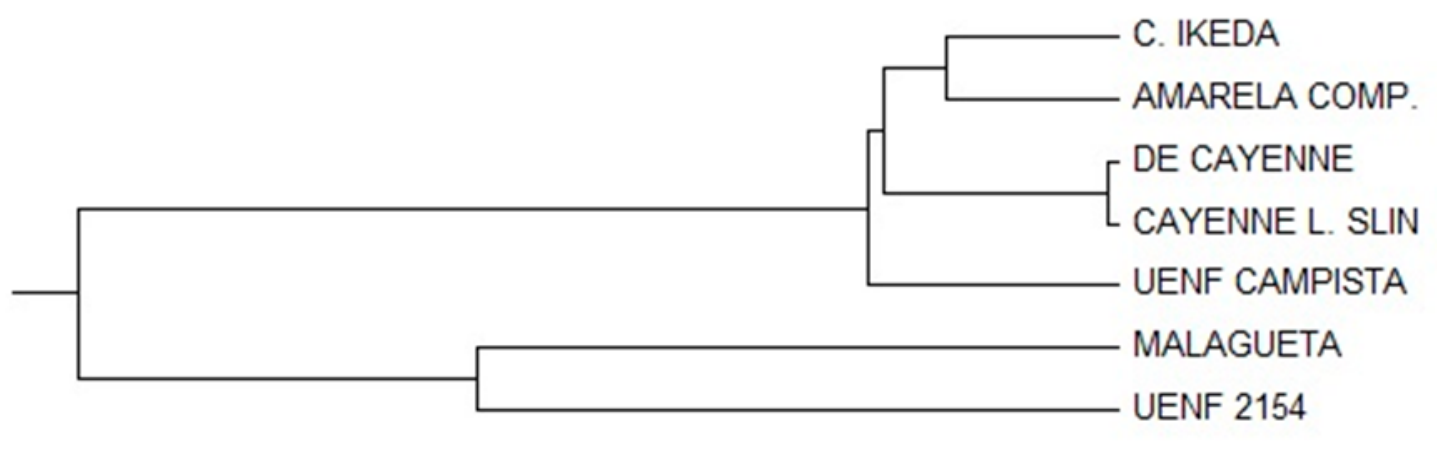

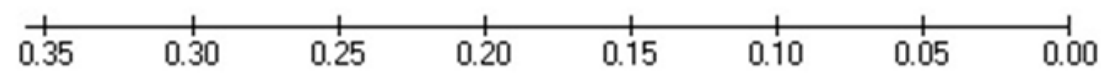

Figure 1. Cluster dendrogram of Capsicum cultivars obtained by UPGMA method. Campos dos Goytacazes, UENF, 2017.

These reports, and the results of this paper, are just a simple sample of the confusion found in the seed market in Brazil. Identically, it is possible that other inconsistencies may exist in the registered cultivar information provided by MAPA in CultivarWeb regarding Capsicum cultivars, as well as for other genera and species. The detection of inconsistencies of this nature undermines the confidence of both farmers and breeders in the guarantees offered to them by government agencies, namely: reliability of the cultivar's genetic identity and quality, and the genetic purity of propagative material to be marketed.

We also highlight that many cultivars of Capsicum and other vegetables registered in Platform CultivarWeb are imported from other countries, not being the result of genetic breeding program carried out in the country. This would not be one of the reasons for the inconsistencies in the available information, as this incorrect identification of the species could be a mistake from the country where the cultivar was developed. Especially in the case of Capsicum plants, it is not uncommon to observe misnamed and identification of species.

We suggest here that MAPA might establish stricter mechanisms for checking and certifying the information provided by the applicant in the cultivar registration application form, in order to avoid the disclosure of inaccurate information. We also recommend a thorough review of the information contained in all cultivar registration processes which have already been completed and whose information is already available on the CultivarWeb platform. 


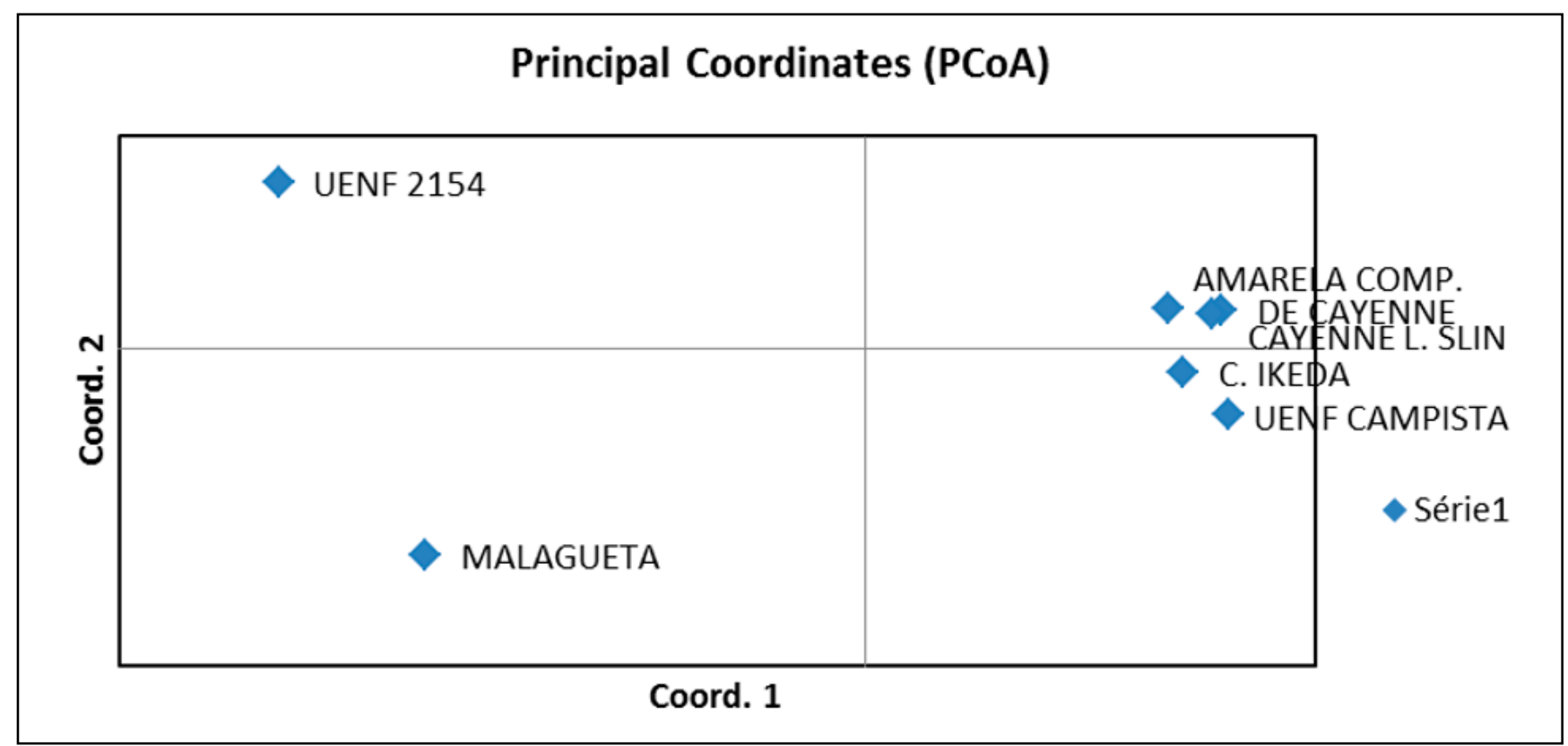

Figure 2. Principal coordinates obtained using dissimilarity matrix resulting from genetic diversity analysis among Capsicum spp. cultivars. Campos dos Goytacazes, UENF, 2017.

We know that monitoring this type of information is complex, since all registration is based on information sent by public or private institution interested in registering a cultivar. For this reason, one proposal which may improve this supervision would be the accreditation of research centers and public universities as certifiers in order to provide accurate information about the cultivar with the Ministério de Agricultura, Pecuária e Abastecimento [(MAPA) Ministry of Agriculture, Livestock and Food Supply]. Adopting some solutions such as the establishment of partner certification institutions, inconsistencies in information contained in the official database for registered cultivars can be avoided and even disappear in the medium term.

Therefore, there is an inconsistency in relation to the information of species of Capsicum attributed to cultivars Amarela Comprida, De Cayenne and Cayenne Long Slin in the official database of the Registro Nacional de Cultivares (National Cultivar Register), CultivarWeb. Consequently, the accuracy of the information presented for other cultivars is not reliable either.

Thus, it is clear that the procedures currently employed for checking and certifying the information provided by the applicant in the cultivar registration application forms need to be reviewed in order to correct and avoid possible inconsistencies in the information available for public consultation, the CultivarWeb.

\section{ACKNOWLEDGEMENTS}

The authors thank to Fundação Carlos Chagas Filho de Amparo à Pesquisa do Estado do Rio de Janeiro (FAPERJ) and Conselho Nacional de Desenvolvimento Científico e Tecnológico (CNPq) for financially supporting this study, in the form of bench rate (processes E-26/202.985/2017 and 307569/20179 , respectively) granted to the second author. This study was supported by Coordenação de Aperfeiçoamento de Pessoal de Nível Superior (CAPES) Financing Code 001.

\section{REFERENCES}

BARBERO, GF; RUIZ, AG; LIAZID, A; PALMA, M; VERA, JC; BARROSO, CG. 2014. Evolution of total and individual capsaicinoids in peppers during ripening of the Cayenne pepper plant (Capsicum annuum L.). Food Chemistry 153: 200-206.

CAMPOS, AL; MAROSTEGA, TN; CABRAL, NSS; ARAÚJO, KL; SERAFIM, ME; SEABRA-JÚNIOR，S; SUDRÉ, C; RODRIGUES, R; NEVES, LG. 2016.
Morphoagronomic and molecular profiling of Capsicum spp. from southwest Mato Grosso, Brazil. Genetics and Molecular Research 15: gmr.15038167.

CARVALHO, C; KIST, BB; TREICHEL, M. 2016. Anuário brasileiro das hortaliças. Santa Cruz do Sul: Editora Gazeta Santa Cruz. 64p.

CARVALHO, SIC; BIANCHETTI, LB; REIFSCHNEIDER, FJB. 2009. Registro e proteção de cultivares pelo setor público: a experiência do programa de melhoramento de Capsicum da Embrapa Hortaliças. Horticultura Brasileira 27: 135-138.

CRUZ, CD. 2013. GENES: software para análise de dados em estatística experimental e em genética quantitativa. Acta Scientiarum Agronomy 35: 271-276.

DOYLE, JJ; DOYLE, JL. 1990. Isolation of plant DNA from fresh tissue. Focus 12: 13-15.

FAVORETTO, P; VEASEY, EA; MELO, PCT. 2011. Molecular characterization of potato cultivars using SSR markers. Horticultura Brasileira 29: 542-547.

KUMAR, LD; KATHIRVEL, M; RAO, GV; NAGARAJU, J. 2001. DNA profiling of disputed chilli samples (Capsicum annuum) using ISSR-PCR and FISSR-PCR marker assays. Forensic Science International 116: 63-68.

KWON, YS; LEE, JM; YI, GB; YI, SI; KIM, KM; SOH, EH; BAE, KM; PARK, EK; SONG, IH; KIM, BD. 2005. Use of SSR markers to complement tests of distinctiveness, uniformity, and stability (DUS) of pepper (Capsicum annuum L.) Varieties. Mol. Cells 19: 428-435.

LEE, JM; NAHM, SH; KIM, YM; KIM, BD. 2004. Characterization and molecular genetic mapping of microsatellite loci in pepper. Theoretical and Applied Genetics 108: 619-627.

LIU, K; MUSE, SV. 2005. PowerMarker: an 
integrated analysis environment for genetic marker analysis. Bioinformatics 21: 21282129.

MINAMIYAMA, Y; TSURO, M; HIRAI, M. 2006. An SSR-based linkage map of Capsicum annuum. Molecular Breeding 18:157-169.

PEAKALL, R; SMOUSE, PE. 2012. GenAlEx 6.5: genetic analysis in Excel. Population genetic software for teaching and research- an update. Bioinformatics 28: 2537-2539.

PIMENTAS ARTESANAIS. 2017. Pimentas Artesanais. Available at http:// pimentasartesanais.com.br/produtos. asp?produto $=2511$. Accessed November 10, 2017.

SILVA, AR; DIAS, CTS. 2013. A cophenetic correlation coefficient for Tocher's method. Pesquisa Agropecuária Brasileira 48: 589596.

SIM, SC; HONG, JH; KWON, YS. 2015. DNA profiling of commercial pumpkin cultivars using simple sequence repeat polymorphisms. Horticulture Environment and Biotechnoogy. 56: 811-820.

SZPIECH, ZA; ROSENBERG, NA. 2011. On the size distribution of private microsatellite alleles. Theoretical Population Biology 80: 100-113.

UPOV - International Union for the Protection of New Varieties of Plants. 2010. Guidelines for DNA-Pofiling: molecular marker selection and database construction ("BMT GUIDELINES”). UPOV/INF/17/1. Geneva, Switzerland. 13p.

YI, G; LEE, JM; LEE, S; CHOI, D; KIM, B. 2006. Exploitation of pepper EST-SSRs and an SSR-based linkage map. Theoretical and Applied Genetics 114: 113-130. 